\title{
ABM Clinical Protocol \#3: Supplementary Feedings in the Healthy Term Breastfed Neonate, Revised
}

2017

\author{
Ann Kellams, ${ }^{1}$ Cadey Harrel, ${ }^{2}$ Stephanie Omage, ${ }^{3}$ Carrie Gregory, ${ }^{4}$ Casey Rosen-Carole ${ }^{5}$ and The Academy of \\ Breastfeeding Medicine
}

A central goal of The Academy of Breastfeeding Medicine is the development of clinical protocols for managing common medical problems that may impact breastfeeding success. These protocols serve only as guidelines for the care of breastfeeding mothers and infants and do not delineate an exclusive course of treatment or serve as standards of medical care. Variations in treatment may be appropriate according to the needs of an individual patient.

\section{Definitions used in this protocol}

- Exclusive breastfeeding: Feeding only breast milk (at the breast or own mothers' expressed breast milk), no food or water except vitamins, minerals and medications.

- Supplementary feedings: Additional fluids provided to a breastfed infant before 6 months (recommended duration of exclusive breastfeeding). These fluids may include donor human milk, infant formula or other breast milk substitutes (eg. glucose water).

- Complementary feedings: Solid or semi-solid foods provided to an infant in addition to breastfeeding when breast milk alone is no longer sufficient to meet nutritional needs.

- Term infant: In this protocol 'term infant' also includes early term infants (gestational age 37-38 6/7 weeks).

\section{Background}

Given early opportunities to breastfeed, breastfeeding assistance, and instruction the vast majority of mothers and infants will successfully establish breastfeeding. Although some infants may not successfully latch and feed well during the first day (24 hours), most will successfully breastfeed with time, appropriate evaluation and

\footnotetext{
${ }^{1}$ Department of Pediatrics, University of Virginia, VA, USA

2 Department of Family \& Community Medicine, University of Arizona College of Medicine and Family Medicine Residency, AZ, USA

${ }^{3}$ Discipline of General Practice, The University of Queensland, Australia

${ }^{4}$ Departments of Pediatrics and OBGYN, University of Rochester, Rochester, NY, USA

${ }^{5}$ Departments of Pediatrics and OBGYN, University of Rochester, Rochester, NY, USA
} 
support, with minimal intervention. Exclusive breastfeeding for the first 6 months is associated with the greatest protection against major health problems for both mothers and infants. ${ }^{1-3}$ Unfortunately, infant formula supplementation of healthy neonates in hospital is commonplace, ${ }^{4,5}$ despite widespread recommendations to the contrary. ${ }^{6-8}$ Early supplementation with infant formula is associated with decreased exclusive breastfeeding rates in the first 6 months and an overall shorter duration of breastfeeding. ${ }^{9,10}$ Therefore, hospitals, healthcare facilities, and community organizations that promote breastfeeding are integral in improving the exclusivity and duration of breastfeeding. ${ }^{10}$ One way of achieving this is by following The Ten Steps to Successful Breastfeeding (the basis for the Baby-Friendly Hospital Initiative), both in the hospital and community.

\section{Newborn physiology}

Small quantities of colostrum are appropriate for the size of a newborn's stomach, ${ }^{11-13}$ prevent hypoglycemia in a healthy, term, appropriate for gestational age infant, ${ }^{14,15}$ and are easy for an infant to manage as he/she learns to coordinate sucking, swallowing, and breathing. Healthy term infants also have sufficient body water to meet their metabolic needs, even in hot climates. ${ }^{16-18}$ Fluid necessary to replace insensible fluid loss is adequately provided by breast milk alone. ${ }^{7,18}$ Newborns lose weight because of physiologic diuresis of extracellular fluid following transition from intrauterine to extrauterine life and the passage of meconium. In a prospective cohort of mothers in a U.S. Baby Friendly-designated hospital with optimal support of infant feeding, the mean weight loss of exclusively breastfed infants was $5.5 \%$; notably, greater than $20 \%$ of healthy breastfed infants lost more than $7 \%$ of their birthweight. ${ }^{19}$ A study of over 160,000 healthy breastfed infants resulted in the creation of hour-specific nomograms for infant weight loss for exclusively breastfed newborns that showed differentially increased weight loss in those born by Cesarean section than by vaginal birth. In this study, almost $5 \%$ of vaginally born infants and $>10 \%$ of those born by Cesarean section had lost $\geq 10 \%$ of their birth weight by 48 hours after birth. By 72 hours, $>25 \%$ of infants born by Cesarean section had lost $\geq 10 \%$ of their birth weight. ${ }^{20}$ Breastfed infants regain birth weight at an average of 8.3 days (95\% confidence interval 7.7-8.9 days) with $97.5 \%$ having regained their birth weight by 21 days. ${ }^{21}$ Infants should be followed closely to identify those who lie outside the predicted pattern, but the majority of those breastfed infants will not require supplementation. It should also be noted that excess newborn weight loss is correlated with positive maternal intrapartum fluid balance (received through intravenous fluids) and may not be directly indicative of breastfeeding success or failure..$^{22,23}$

\section{Early management of the new breastfeeding mother}

Some breastfeeding mothers question the adequacy of colostrum feedings and perceive that they have an insufficient milk supply. ${ }^{24,25}$ These women may receive conflicting advice about the need for supplementation 
and would benefit from reassurance, assistance with breastfeeding technique, and education about the normal physiology of breastfeeding and infant behavior. Inappropriate supplementation may undermine a mother's confidence in her ability to meet her infant's nutritional needs ${ }^{26}$ and give inappropriate messages that may result in supplementation of breastfed infants at home. ${ }^{27}$ Introduction of infant formula or other supplements may decrease the feeding frequency of the infant, thereby decreasing the amount of breast stimulation a mother receives which results in a reduction of milk supply. ${ }^{28}$

Postpartum mothers with low confidence levels are very vulnerable to external influences, such as advice to offer breastfeeding infants supplementation of glucose water or infant formula. Well-meaning healthcare professionals may recommend supplementation as a means of protecting mothers from fatigue or distress, although this can conflict with their role in promoting breastfeeding. ${ }^{29-31}$ Several sociodemographic factors are associated with formula supplementation in the hospital, and vary geographically. It is important to recognize and address these factors in a culturally sensitive manner. Inappropriate reasons for supplementation and associated risks are multiple (Appendix 1).

There are common clinical situations where evaluation and breastfeeding management may be necessary, but SUPPLEMENTATION IS NOT INDICATED, including:

1. The healthy, term, appropriate for gestational age infant when the infant is feeding well, urinating and stooling adequately, weight loss in the expected range and bilirubin levels are not of concern (depending on gestational age, time since birth and any risk factors). ${ }^{32}$

- Newborns are normally sleepy after an initial alert period after birth (approximately 2 hours). They then have variable sleep-wake cycles, with an additional one or two wakeful periods in the next 10 hours whether fed or not. ${ }^{33}$

- Careful attention to an infant's early feeding cues, keeping the infant safely skin-to-skin with mother when she is awake, gently rousing the infant to attempt frequent breastfeeds, and teaching the mother hand expression of drops of colostrum, ${ }^{34}$ may be more appropriate than automatic supplementation after $6,8,12$, or even 24 hours.

- Increased skin-on-skin time can encourage more frequent feeding.

- $10 \%$ weight loss is not an automatic marker for the need for supplementation, but is an indicator for infant evaluation.

2. The infant who is fussy at night or constantly feeding for several hours 
- Cluster feeding (several short feeds close together) is normal newborn behavior, but should warrant a feeding evaluation to observe the infant's behavior at the breast ${ }^{35}$ and the comfort of the mother to ensure that the infant is latched deeply and effectively.

- Some fussy infants are in pain that should be addressed.

3. The tired or sleeping mother

- Some fatigue is normal for new mothers. However, rooming out for maternal fatigue does not improve mothers' sleep time, ${ }^{36}$ and has been shown to reduce breastfeeding exclusivity. ${ }^{37}$ Extreme fatigue should be evaluated for the safety of mother and baby, to avoid falls and suffocation. ${ }^{38}$

- Breastfeeding management that optimizes the infant feeding at the breast may make for a more satisfied infant AND allow the mother to get more rest.

The following guidelines address strategies to prevent the need for supplementation as well as indications for and methods of supplementation for the healthy, term (37-42-week), breastfed infant. Indications for supplementation in term, healthy infants are few. ${ }^{7,39}$ Table 1 lists possible indications for the administration of supplemental feeds. In each case, the medical provider must decide if the clinical benefits outweigh the potential negative consequences of such feedings.

\section{Recommendations}

\section{Step 1. Prevent the need for supplementation}

1. There is mixed, but mainly positive evidence about the role of antenatal education and in-hospital support on the rates of exclusive breastfeeding. ${ }^{40-42}$ (I) (Quality of evidence [Levels of evidence I, II-1, II2, II-3, and III] is based on the U.S. Preventive Services ${ }^{43}$ Task Force Appendix A Task Force Ratings and is noted in parentheses.)

2. All staff who care for postpartum women should be able to assist and assess breastfeeding infants, especially when other staff with expertise are not available.

3. Both mothers and healthcare professionals should be aware of the risks of unnecessary supplementation.

4. Healthy infants should be placed skin-to-skin with the mother, if she is awake and alert, immediately after birth to facilitate breastfeeding. ${ }^{7,44}(\mathrm{I})$ The delay in time between birth and initiation of the first 
breastfeed is a strong predictor of infant formula use and may affect future milk supply. ${ }^{10,45,46}$ (II-3,II-2, II-3)

5. It is ideal to have the mother and infant room-in 24 hours per day to respond to infant feeding cues, enhance opportunities for breastfeeding and hence secretory activation (lactogenesis II)..$^{7,39,47,48}$ (III)

6. If mother-infant separation is unavoidable, milk supply is not well established, or milk transfer is inadequate, the mother needs instruction and encouragement to express her milk by hand or pump to stimulate milk production and provide expressed milk for the infant. ${ }^{7,39,48,49}(\mathrm{I}, \mathrm{III})$ This process should begin within 1 hour of birth. ${ }^{45}$ (II-2)

\section{Step 2. Address early indicators of the possible need for supplementation}

1. The infant's medical providers should be notified if the infant or mother meet any criteria for supplementation, as listed in Table 1.

Z. All infants must be formally evaluated for position, latch, and milk transfer prior to the provision of supplemental feedings. This evaluation should be undertaken by a healthcare provider with expertise in breastfeeding management, when available.,48

\section{Step 3. Determine whether supplementation is required and supplement with care}

1. The status of the infant requiring supplementation should be determined and any decisions made on a case-by-case basis (guidelines in Table 1).

2. Hospitals should strongly consider formulating and instituting policies to require a medical provider's order when supplements are medically indicated and informed consent of the mother when supplements are not medically indicated. It is the responsibility of the healthcare provider to fully inform parents of the benefits and risks of supplementation, document parental decisions, and support the parents after they have made a decision. ${ }^{50,51}$ (III)

3. All supplemental feedings should be documented, including the content, volume, method, and medical indication or reason.

4. When supplementary feeding is medically necessary, the primary goals are to feed the infant and to optimize the maternal milk supply while determining the cause of low milk supply, poor feeding or inadequate milk transfer. Supplementation should be performed in ways that help preserve breastfeeding such as limiting the volume to what is necessary for the normal newborn physiology, avoiding teats/artificial nipples, ${ }^{52}$ (I) stimulating the mother's breasts with hand expression or pumping, and for the infant to continue to practice at the breast. 
7. Optimally, mothers need to express milk frequently, usually once for each time the infant receives a supplement, or at least 8 times in 24 hours if the infant is not feeding at the breast. Breasts should be fully-drained each time..$^{53}$ (II-2) Maternal breast engorgement should be avoided as it will further compromise the milk supply and may lead to other complications. ${ }^{54}$ (III)

8. Criteria for stopping supplementation should be considered from the time of the decision to supplement and should be discussed with the parents. Stopping supplementation can be a source of anxiety for parents and providers. Underlying factors should be addressed and mothers should be assisted with their milk supply, latch, and comfort with assessing the signs that their infant is adequately fed. It is important to closely follow up mother and infant.

9. When the decision to supplement is not medically indicated (see Table 1), discussions with the mother should be documented by the nursing and/or medical staff followed by full support of her informed decision.

\section{Choice of Supplement}

1. Expressed breast milk from the infant's mother is the first choice for extra feeding for the breastfed infant. ${ }^{7,55}$ (III) Hand expression may elicit larger volumes than a breast pump in the first few days following birth and may increase overall milk supply..$^{56}$ Breast massage and/or compression along with expressing with a mechanical pump may also increase available milk. ${ }^{57}$ (II-3)

2. If the volume of the mother's own colostrum/milk does not meet her infant's feeding requirements and supplementation is required, donor human milk is preferable to other supplements. ${ }^{55}$

3. When donor human milk is not available or appropriate, protein hydrolysate formulas may be preferable to standard infant formula as they avoid exposure to intact cows milk proteins and reduce bilirubin levels more rapidly, ${ }^{58}$ (II-2) though recent data is less supportive of its role in preventing allergic disease..$^{59}$ (I) The use of this type of formula may also convey the psychological message that the supplement is a temporary therapy, not a permanent inclusion of artificial feedings.

4. Supplementation with glucose water is not appropriate because it does not provide sufficient nutrition, does not reduce serum bilirubin, ${ }^{60,61}$ and might cause hyponatremia.

5. The potential risks and benefits of other supplemental fluids, such as cows milk formulas, soy formulas, or protein hydrolysate formulas, must be considered along with the available resources of the family, the infant's age, the amounts needed, and the potential impact on the establishment of breastfeeding.

\section{Volume of Supplemental Feeding}


1. Several studies give us an idea of intakes at the breast over time. In most studies, the range of intake is wide, while formula-fed infants usually take in larger volumes than breastfed infants. ${ }^{62-66}$ (II-3)

2. Infants fed infant formula ad libitum commonly have much higher intakes than breastfed infants. ${ }^{65,66}$ (II-3) Acknowledging that ad libitum breastfeeding emulates evolutionary feeding and considering recent data on obesity in formula-fed infants, it appears that formula-fed infants may be overfed.

3. As there is no definitive research available, the amount of supplement given should reflect the normal amounts of colostrum available, the size of the infant's stomach (which changes over time), and the age and size of the infant. Intake on day 2 post birth is generally higher than day 1 in relation to infant's demand. ${ }^{65}$

4. Based on the limited research available, suggested intakes for healthy, term infants are given in Table 2, although feedings should be based on infant cues.

\section{Methods of Providing Supplementary Feedings}

1. When supplementary feedings are needed, there are a number of delivery methods from which to choose: a supplemental nursing device at the breast, cup feeding, spoon or dropper feeding, fingerfeeding, syringe feeding, or bottle feeding. ${ }^{67}$ (III)

2. An optimal supplemental feeding device has not yet been identified, and may vary from one infant to another. No method is without potential risk or benefit. ${ }^{68}$

3. When selecting an alternative feeding method, clinicians should consider several criteria:
a. cost and availability
b. ease of use and cleaning
c. stress to the infant
d. whether adequate milk volume can be fed in 20-30 minutes
e. whether anticipated use is short- or long-term
f. maternal preference
g. expertise of healthcare staff
h. whether the method enhances development of breastfeeding skills. 
4. There is no evidence that any of these methods are unsafe or that one is necessarily better than the other. There is some evidence that avoiding teats/artificial nipples for supplementation may help the infant return to exclusive breastfeeding ${ }^{20,52,69}$ (I); however, when hygiene is suboptimal, cup feeding is the recommended choice. ${ }^{55}$ Cup feeding also allows infants to control feeding pace ${ }^{68}$ (II-2). Cup feeding has been shown safe for both term and preterm infants and may help preserve breastfeeding duration among those who require multiple supplemental feedings. ${ }^{52,70-72}$ (II-2, I, I, I, II-2)

5. If bottles are being used, pacing the feed may be beneficial, especially for preterm infants. ${ }^{73}$ (III)

6. Supplemental nursing systems have the advantages of supplying a supplement while simultaneously stimulating the breast to produce more milk, reinforcing the infant's feeding at the breast, enabling the mother to have a breastfeeding experience and encouraging skin to skin. However, mothers may find the systems awkward to use, difficult to clean, relatively expensive, requiring moderately complex learning, and the infant must be able to latch effectively. ${ }^{67} \mathrm{~A}$ simpler version, supplementing with a dropper, syringe or feeding tube attached to the breast while the infant is feeding at breast, may be effective.

7. Bottle-feeding is the most commonly used method of supplementation in more affluent regions of the world, but concerns have been raised because of distinct differences in tongue and jaw movements, and faster flow may result in higher (and unnecessary) volumes of feeds. ${ }^{67}$ Some experts have recommended a teat/nipple with a wide base and slow flow to try to mimic breastfeeding and to avoid nipple confusion or preference, ${ }^{68,74}(\mathrm{II}-2)$, but little research has been done evaluating outcomes with different teats/nipples.

\section{Research Needs}

Research is necessary to establish evidence-based guidelines on appropriate supplementation volumes for specific conditions and whether this varies for colostrum versus infant formula.

Specific questions include:

1. Should the volume be independent of infant weight or a per kg volume? Should supplementation make up for cumulative losses?

2. Should feeding intervals or quantities be different for different types of delivery of supplementation (e.g. bottles, cup feeding)?

3. Are some methods (type and delivery mechanism) best for infants with certain conditions, ages, and available resources? Which methods interfere least with establishing direct breastfeeding? 


\section{Notes}

This protocol addresses the healthy, term newborn. For information regarding appropriate feeding and supplementation for the late preterm infant (35-37 weeks), see "ABM Protocol \#10: Breastfeeding the Late Preterm Infant" 75 and "Care and Management of the Late Preterm Infant Toolkit." ${ }^{16}$ The World Health Organization broadened the annex of the "Global Criteria for the Baby Friendly Hospital Initiative: "Acceptable Medical Reasons for Supplementation."77 to include acceptable reasons for use of breast milk substitutes in all infants. The handout (\#4.5) is available at: http://www.who.int/nutrition/topics/BFHI Revised Section 4.pdf.

\section{References}

1. Kramer MS, Kakuma R. Optimal duration of exclusive breastfeeding. Cochrane Database Syst Rev. 2012;Issue:8:CD003517.

2. Smith HA, Becker GE. Early additional food and fluids for healthy breastfed full-term infants. Cochrane Database Syst Rev. 2016;Issue:8:CD006462.

3. Victora CG, Bahl R, Barros AJD, et al. Breastfeeding in the 21st century: epidemiology, mechanisms, and lifelong effect. Lancet. 2016;387(10017):475-490.

4. Biro MA, Sutherland GA, Yelland JS, Hardy P, Brown SJ. In-hospital formula supplementation of breastfed babies: a population-based survey. Birth. 2011;38(4):302-310.

5. Boban M, Zakarija-Grkovic I. In-hospital formula supplementation of healthy newborns: practices, reasons and their medical justification. Breastfeed Med. 2016;11(9):448-454.

6. World Health Organization. The optimal duration of exclusive breastfeeding: a systematic review. Geneva: WHO 2002.

7. American Academy of Pediatrics Section on Breastfeeding. Breastfeeding and the use of human milk. Pediatrics. 2012;129(2):827-841.

8. National Health and Medical Research Council. Infant feeding guidelines. Canberra: National Health and Medical Research Council; 2012.

9. Dabritz HA, Hinton BG, Babb J. Maternal hospital experiences associated with breastfeeding at 6 months in a northern California county. J Hum Lact. 2010;26(3):274-285.

10. Perrine CG, Scanlon KS, Li R, Odom E, Grummer-Strawn LM. Baby-Friendly hospital practices and meeting exclusive breastfeeding intention. Pediatrics. 2012;130(1):54-60.

11. Naveed M, Manjunath CS, Sreenivas V. An autopsy study of relationship between perinatal stomach capacity and birth weight. Indian J Gastroenterol. 1992;11(4):156-158.

12. Zangen S, Di Lorenzo C, Zangen T, Mertz H, Schwankovsky L, Hyman PE. Rapid maturation of gastric relaxation in newborn infants. Pediatr Res. 2001;50(5):629-632. 
13. Scammon R, Doyle L. Observations on the capacity of the stomach in the first ten days of postnatal life. Am J Dis Child. 1920;20:516-538.

14. Wight NE. Hypoglycemia in breastfed neonates. Breastfeed Med. 2006;1(4):253-262.

15. Wight N, Marinelli KA. ABM clinical protocol \#1: Guidelines for blood glucose monitoring and treatment of hypoglycemia in term and late-preterm neonates, Revised 2014. Breastfeed Med. 2014;9(4):173179.

16. Cohen RJ, Brown KH, Rivera LL, Dewey KG. Exclusively breastfed, low birthweight term infants do not need supplemental water. Acta Paediatr. 2000;89(5):550-552.

17. Marchini G, Stock S. Thirst and vasopressin secretion counteract dehydration in newborn infants. J Pediatr. 1997;130(5):736-739.

18. Sachdev HP, Krishna J, Puri RK. Do exclusively breast fed infants need fluid supplementation? Indian Pediatr. 1992;29(4):535-540.

19. Grossman X, Chaudhuri JH, Feldman-Winter L, Merewood A. Neonatal weight loss at a US BabyFriendly Hospital. J Acad Nutr Diet. 2012;112(3):410-413.

20. Flaherman VJ, Schaefer EW, Kuzniewicz MW, Li SX, Walsh EM, Paul IM. Early weight loss nomograms for exclusively breastfed newborns. Pediatrics. 2015;135(1):e16-e23.

21. Macdonald PD, Ross SR, Grant L, Young D. Neonatal weight loss in breast and formula fed infants. Arch Dis Child. 2003;88(6):F472-476.

22. Noel-Weiss J, Woodend A, Peterson W, Gibb W, Groll D. An observational study of associations among maternal fluids during parturition, neonatal output, and breastfed newborn weight loss. Int Breastfeed J. 2011;6:9.

23. Chantry C, Nommsen-Rivers L, Peerson J, Cohen R, Dewey K. Excess weight loss in first-born breastfed newborns relates to maternal intrapartum fluid balance. Pediatrics. 2011;127(1):171-179.

24. Gatti L. Maternal perceptions of insufficient milk supply in breastfeeding. J Nurs Scholarsh. 2008;40(4):355-363.

25. Robert E, Coppieters $Y$, Swennen B, Dramaix M. The reasons for early weaning, perceived insufficient breast milk, and maternal dissatisfaction: Comparative studies in two Belgian regions. Int Sch Res Notices. 2014;2014:678564-678564.

26. Blyth R, Creedy DK, Dennis C-L, Moyle W, Pratt J, De Vries SM. Effect of maternal confidence on breastfeeding duration: an application of breastfeeding self-efficacy theory. Birth. 2002;29(4):278-284.

27. Reif M, Essock-Vitale S. Hospital influences on early infant-feeding practices. Pediatrics. 1985;76:872879.

28. Crowley WR. Neuroendocrine regulation of lactation and milk production. Evaluation. 2015;5(1):255291. 
29. Cloherty M, Alexander J, Holloway I. Supplementing breast-fed babies in the UK to protect their mothers from tiredness or distress. Midwifery. 2004;20(2):194-204.

30. Kurinij N, Shiono PH. Early formula supplementation of breast-feeding. Pediatrics. 1991;88(4):745-750.

31. Akuse RM, Obinya EA. Why healthcare workers give prelacteal feeds. Eur J Clin Nutr. 2002;56(8):729734.

32. American Academy of Pediatrics Subcommittee on Hyperbilirubinemia. Management of hyperbilirubinemia in the newborn infant 35 or more weeks of gestation. Pediatrics. 2004;114(1):297316.

33. Emde RN, Swedberg J, Suzuki B. Human wakefulness and biological rhythms after birth. Arch Gen Psychiatry. 1975;32(6):780-783.

34. Flaherman VJ, Gay B, Scott C, Avins A, Lee KA, Newman TB. Randomised trial comparing hand expression with breast pumping for mothers of term newborns feeding poorly. Arch Dis Child. 2012;97(1):F18-F23.

35. Berens P, Eglash A, Malloy M, Steube AM. ABM Clinical Protocol \#26: Persistent pain with breastfeeding. Breastfeed Med. 2016;11(2):46-53.

36. Waldenström U, Swenson A. Rooming-in at night in the postpartum ward. Midwifery. 1991;7(2):82-89.

37. Jaafar SH, Ho JJ, Lee KS. Rooming-in for new mother and infant versus separate care for increasing the duration of breastfeeding. Cochrane Database Syst Rev. 2016;Issue:8:CD006641.

38. Feldman-Winter L, Goldsmith JP. Safe sleep and skin-to-skin care in the neonatal period for healthy term newborns. Pediatrics. 2016;138(3).

39. World Health Organization. Evidence for the ten steps to successful breastfeeding. Geneva: WHO;1998.

40. Su L-L, Chong Y-S, Chan Y-H, et al. Antenatal education and postnatal support strategies for improving rates of exclusive breast feeding: randomised controlled trial. BMJ. 2007;335:596-596.

41. Lumbiganon P, Martis R, Laopaiboon M, Festin MR, Ho JJ, Hakimi M. Antenatal breastfeeding education for increasing breastfeeding duration. Cochrane Database Syst Rev. 2016;Issue:12:CD006425.

42. Balogun OO, O'Sullivan EJ, McFadden A, et al. Interventions for promoting the initiation of breastfeeding. Cochrane Database Syst Rev. 2016;Issue:11:Art. No.: CD001688.

43. Guide to Clinical Preventive Services, 2nd edition; Report of the U.S. Preventive Services Task Force. US Preventive Services Task Force Washington (DC). US Department of Health and Human Services. 1996. http://www.ncbi.nlm.nih.gov/books/NBK15430/. Accessed Jan 4th, 2016.

44. Moore ER, Bergman N, Anderson GC, Medley N. Early skin-to-skin contact for mothers and their healthy newborn infants. Cochrane Database Syst Rev. 2016;Issue:11:CD003519. 
45. Parker LA, Sullivan S, Krueger C, Mueller M. Association of timing of initiation of breastmilk expression on milk volume and timing of lactogenesis stage II among mothers of very low-birth-weight infants. Breastfeed Med. 2015;10(2):84-91.

46. Parry JE, Ip DKM, Chau PYK, Wu KM, Tarrant M. Predictors and consequences of in-hospital formula supplementation for healthy breastfeeding newborns. J Hum Lact. 2013;29(4):527-536.

47. Pang WW, Hartmann PE. Initiation of human lactation: secretory differentiation and secretory activation. J Mammary Gland Biol Neoplasia. 2007;12:211-221.

48. International Lactation Consultants Association. Clinical Guidelines for the Establishment of Exclusive Breastfeeding. 3rd ed: ILCA; 2014.

49. Becker GE, Smith HA, Cooney F. Methods of milk expression for lactating women. Cochrane Database Syst Rev. 2016;Issue:9:CD006170.

50. Academy of Breastfeeding Medicine Protocol Committee. ABM Clinical Protocol \#7: Model breastfeeding policy (Revision 2010). Breastfeed Med. 2010;5(4):173-177.

51. Hawke BA, Dennison BA, Hisgen S. Improving hospital breastfeeding policies in New York State: development of the model hospital breastfeeding policy. Breastfeed Med. 2013;8(1):3-7.

52. Howard CR, Howard FM, Lanphear B, et al. Randomized clinical trial of pacifier use and bottle-feeding or cupfeeding and their effect on breastfeeding. Pediatrics. 2003;111(3):511-518.

53. Hill PD, Aldag JC, Chatterton RT. Initiation and frequency of pumping and milk production in mothers of non-nursing preterm infants. J Hum Lact. 2001;17(1):9-13.

54. Berens P, Brodribb W. ABM Clinical Protocol \#20: Engorgement, Revised 2016. Breastfeed Med. 2016;11:159-163.

55. World Health Organization. Global strategy for infant and young child feeding. Geneva: WHO; 2003.

56. Morton J, Hall JY, Wong RJ, Thairu L, Benitz WE, Rhine WD. Combining hand techniques with electric pumping increases milk production in mothers of preterm infants. J Perinatol. 2009;29(11):757-764.

57. Morton J, et al. Breast massage maximizes milk volumes of pump-dependent mothers [abstract 7720.9]. Pediatric Academic Societies Scientific Program. Toronto: Pediatric Academic Societies; 2007.

58. Gourley GR, Li Z, Kreamer BL, Kosorok MR. A controlled, randomized, double-blind trial of prophylaxis against jaundice among breastfed newborns. Pediatrics. 2005;116(2):385-391.

59. Boyle RJ, lerodiakonou D, Khan T, et al. Hydrolysed formula and risk of allergic or autoimmune disease: systematic review and meta-analysis. BMJ (Clinical Research Ed.). 2016;352:i974-i974.

60. de Carvalho M, Hall M, Harvey D. Effects of water supplementation on physiological jaundice in breastfed babies. Arch Dis Child. Jul 1981;56(7):568-569.

61. Nicoll A, Ginsburg R, Tripp JH. Supplementary feeding and jaundice in newborns. Acta Paediatr Scand. Sep 1982;71(5):759-761. 
62. Saint L, Smith M, Hartmann PE. The yield and nutrient content of colostrum and milk of women from giving birth to 1 month post-partum. Br J Nutr. 1984;52(1):87-95.

63. Casey CE, Neifert MR, Seacat JM, Neville MC. Nutrient intake by breast-fed infants during the first five days after birth. Am J Dis Child. 1986;140(9):933-936.

64. Evans K, Evans R, Royal R, Esterman A, James S. Effect of casearean section on breast milk transfer to the normal term newborn over the first week of life. Arch Dis Child. 2003;88:F380-382.

65. Dollberg S, Lahav S, Mimouni FB. A comparison of intakes of breast-fed and formula-fed infants during the first two days of life. J Am Coll Nutr. 2001;20(3):209-211.

66. Davila-Grijalva H, Troya AH, Kring E, DeRidder J, Maisels MJ. How Much Do Formula-Fed Infants Take in the First 2 Days? Clin Pediatr (Phila). Mar 21 2017;56(1):46-48.

67. Wight NE. Management of common breastfeeding issues. Pediatr Clin North Am. 2001;48(2):321-344.

68. Cloherty M, Alexander J, Holloway I, Galvin K, Inch S. The cup-versus-bottle debate: a theme from an ethnographic study of the supplementation of breastfed infants in hospital in the United kingdom. $J$ Hum Lact. 2005;21(2):151-162.

69. Flint A, New K, Davies MW. Cup feeding versus other forms of supplemental enteral feeding for newborn infants unable to fully breastfeed. Cochrane Database Syst Rev. 2016;Issue:8:CD005092.

70. Howard CR, de Blieck EA, ten Hoopen CB, Howard FM, Lanphear BP, Lawrence RA. Physiologic stability of newborns during cup- and bottle-feeding. Pediatrics. 1999;104(5 Pt 2):1204-1207.

71. Malhotra N, Vishwambaran L, Sundaram KR, Narayanan I. A controlled trial of alternative methods of oral feeding in neonates. Early Hum Dev. 1999;54(1):29-38.

72. Marinelli KA, Burke GS, Dodd VL. A comparison of the safety of cupfeedings and bottlefeedings in premature infants whose mothers intend to breastfeed. J Perinatol. 2001;21(6):350-355.

73. Kassing D. Bottle-feeding as a tool to reinforce breastfeeding. J Hum Lact. 2002;18(1):56-60.

74. Neifert M, Lawrence R, Seacat J. Nipple confusion: Towards a formal definition. J Pediatr. 1995;126:S125-S129.

75. Boies E, Vaucher Y. ABM Clinical Protocol \#10: Breastfeeding the late preterm (34-36 6/7 weeks of gestation) and early term infants (37-38 6/7 weeks of gestation), second revision 2016. Breastfeed Med. 2016;11(10):494-500.

76. California Perinatal Quality Care Collaborative. Care and management of the late preterm infants toolkit. 2013; https://www.cpqcc.org/sites/default/files/Late Preterm Infant Toolkit FINAL 2-13.pdf. Accessed 25 Aug, 2016.

77. UNICEF/WHO. Baby Friendly Hospital Initiative, revised, updated and expanded for integrated care, Section 4, Hospital Self-Appraisal and Monitoring. 2006:

http://www.who.int/nutrition/topics/BFHI_Revised_Section_4.pdf. Accessed 21 Nov 2016. 
78. Weston P, Harris D, Battin M, Brown J, Hegarty J, Harding J. Oral dextrose gel for the treatment of hypoglycaemia in newborn infants. Cochrane Database Syst Rev. 2016;Issue:5:CD011027.

79. Boskabadi H, Maamouri G, Ebrahimi M, et al. Neonatal hypernatremia and dehydration in infants receiving inadequate breastfeeding. Asia Pac J Clin Nutr. 2010;19(3):301-307.

80. Neifert MR. Prevention of breastfeeding tragedies. Pediatr Clin North Am. 2001;48(2):273-297.

81. Nommsen-Rivers LA, Heinig MJ, Cohen RJ, Dewey KG. Newborn wet and soiled diaper counts and timing of onset of lactation as indicators of breastfeeding inadequacy. J Hum Lact. 2008;24(1):27-33.

82. Thuiler D. Challenging expected patterns of weight loss in full-term breastfeeding neonates born by Cesarean. J Obstet Gynecol Neonatal Nurs. 2017;46(1):18-28.

83. Shrago LC, Reifsnider E, Insel K. The Neonatal Bowel Output Study: indicators of adequate breast milk intake in neonates. Pediatr Nurs. 2006;32(3):195-201.

84. Neifert MR, DeMarzo S, Seacat JM, Young D, Leff M, Orleans M. The influence of breast surgery, breast appearance, and pregnancy-induced breast changes on lactation sufficiency as measured by infant weight gain. Birth. 1990;17(1):31-38.

85. Huggins K, Petok E, Mireles O. Markers of lactation insufficiency: A study of 34 mothers. In: Auerbach K, ed. Current Isues in Clinical Lactation. Sudbury: Jones \& Bartlett; 2000:27-35.

86. Bullen CL, Tearle PV, Stewart MG. The effect of "humanised" milks and supplemented breast feeding on the faecal flora of infants. J Med Microbiol. 1977;10(4):403-413.

87. Goldsmith F, O'Sullivan A, Smilowitz JT, Freeman SL. Lactation and intestinal Mmcrobiota: How early diet shapes the infant gut. J Mammary Gland Biol Neoplasia. 2015;20(3-4):149-158.

88. Liao S-L, Lai S-H, Yeh K-W, et al. Exclusive breastfeeding is associated with reduced cow's milk sensitization in early childhood. Pediatr Allergy Immunol. 2014;25(5):456-461.

89. Saarinen K, Juntunen-Backman K, Järvenpää A, et al. Supplementary feeding in maternity hospitals and the risk of cow's milk allergy: A prospective study of 6209 infants. J Allergy Clin Immunol. 1999;104:457-461.

90. De Carvalho M, Hall M, Harvey D. Effects of water supplementation on physiological jaundice in breastfed babies. Arch Dis Child. 1981;56(7):568-569.

91. Glover J, Sandilands M. Supplementation of breastfeeding infants and weight loss in hospital. J Hum Lact. 1990;6(4):163-166.

92. Martens P, Phillips S, Cheang M, Rosolowich V. How baby-friendly are Manitoba hospitals? The Provincial Infant Feeding Study. Breastfeeding Promotion Steering Committee of Manitoba. Can J Public Health. 2009;91:51-57.

93. De Carvalho M, Klaus MH, Merkatz RB. Frequency of breast-feeding and serum bilirubin concentration. Am J Dis Child. 1982;136(8):737-738. 
94. Yamauchi Y, Yamanouchi I. Breast-feeding frequency during the first 24 hours after birth in full-term neonates. Pediatrics. 1990;86:171-175.

95. Kumar A, Pant P, Basu S, Rao GRK, Khanna HD. Oxidative stress in neonatal hyperbilirubinemia. J Trop Pediatr. 2007;53(1):69-71.

96. Van Den Driessche M, Peeters K, Marien P, Ghoos Y, Devlieger H, Veereman-Wauters G. Gastric emptying in formula-fed and breast-fed infants measured with the 13C-octanoic acid breath test. J Pediatr Gastroenterol Nutr. 1999;29(1):46-51.

97. Matheny RJ, Birch LL, Picciano MF. Control of intake by human-milk-fed infants: relationships between feeding size and interval. Dev Psychobiol. 1990;23(6):511-518.

98. Pérez-Escamilla R, Segura-Millán S, Canahuati J, Allen H. Prelacteal feeds are negatively associated with breast-feeding outcomes in Honduras. J Nutr. 1996;126(11):2765-2773.

99. Hale T, Rowe H. Medications and Mother's Milk. 17th ed. New York: Springer Publishing Company; 2017.

100. Pease AS, Fleming PJ, Hauck FR, et al. Swaddling and the risk of Sudden Infant Death Syndrome: A meta-analysis. Pediatrics. 2016;137(6):e20153275.

101. Bystrova K, Matthiesen A, Widstrom A, et al. The effect of Russian Maternity Home routines on breastfeeding and neonatal weight loss with special reference to swaddling. Early Hum Dev. 2007;83(1):29-39.

102. Gagnon A, Leduc G, Waghorn K, Yang H, Platt R. In-hospital formula supplementation of healthy breastfeeding newborns. J Hum Lact. 2005;21:397-405.

103. Slaven S, Harvey D. Unlimited suckling time improves breastfeeding. Lancet. 1981;1(8216):392-393.

104. Geddes DT, Langton DB, Gollow I, Jacobs LA, Hartmann PE, Simmer K. Frenulotomy for breastfeeding infants with ankyloglossia: effect on milk removal and sucking mechanism as imaged by ultrasound. Pediatrics. 2008;122(1):e188-e194.

\section{ABM protocols expire 5 years from the date of publication.}

Content of this protocol is up-to-date at the time of publication. Evidence based revisions are made within five years or sooner if there are significant changes in the evidence.

The 2009 edition of this protocol was authored by Nancy E. Wight and Robert Cordes,

The Academy of Breastfeeding Medicine Protocol Committee

Wendy Brodribb MBBS PhD FABM, Chairperson 
Larry Noble MD FABM, Translations Chairperson

Nancy Brent MD

Maya Bunik MD MSPH FABM

Cadey Harrel MD

Ruth A Lawrence MD FABM

Kathleen A. Marinelli MD FABM

Sarah Reece-Stremtan MD

Casey Rosen-Carole MD MPH MSEd

Tomoko Seo MD FABM

Rose St. Fleur MD

Michal Young MD

For correspondence: abm@bfmed.org 
TABLE 1. Possible Indications for Supplementation in Healthy, Term Infants ( $37-416 / 7$ weeks gestational age)

1. Infant indications

a. Asymptomatic hypoglycemia, documented by laboratory blood glucose measurement (not bedside screening methods) that is unresponsive to appropriate frequent breastfeeding. Note that $40 \%$ dextrose gel applied to the side of the infant's cheek is effective in increasing blood glucose levels in this scenario and improves the rate of exclusive breastfeeding after discharge with no evidence of adverse effects. ${ }^{78}$ Symptomatic infants or infants with glucose $<1.4 \mathrm{mmol} / \mathrm{L}$ $(<25 \mathrm{mg} / \mathrm{dl})$ in the first 4 hours of $<2.0 \mathrm{mmol} / \mathrm{L}(<35 \mathrm{mg} / \mathrm{dl})$ after 4 hours should be treated with intravenous glucose. ${ }^{15}$ Breastfeeding should continue during IV glucose therapy.

b. Signs or symptoms that may indicate inadequate milk intake:

i. Clinical or laboratory evidence of significant dehydration (e.g., high sodium, poor feeding, lethargy, etc.) that is not improved after skilled assessment and proper management of breastfeeding. ${ }^{79}$

ii. Weight loss of $\geq 8-10 \%$ (day 5 [120 hours] or later), or weight loss greater than 75 th percentile for age.

1. Although weight loss in the range of $8-10 \%$ may be within normal limits if all else is going well and the physical examination is normal, it is an indication for careful assessment and possible breastfeeding assistance. Weight loss in excess of this may be an indication of inadequate milk transfer or low milk production, but a thorough evaluation is required before automatically ordering supplementation. ${ }^{19,20,80}$

2. Weight loss nomograms for healthy newborns by hour of age can be found at: www.newbornweight.org. ${ }^{20,80}$

iii. Delayed bowel movements, fewer than 4 stools on day 4 of life, or continued meconium stools on day 5 (120 hours). ${ }^{48,80}$

1. Elimination patterns for newborns for urine and stool should be tracked at least through to the onset of secretory activation. Even though there is a wide variation between infants, the patterns may be useful in determining adequacy of breastfeeding. ${ }^{81,82} \mathrm{II}-2$. Newborns with more bowel movements during the 
first 5 days following birth have less initial weight loss, earlier the transition to yellow stools, and earlier return to birth weight. ${ }^{83}$

c. Hyperbilirubinemia (see ABM Clinical Protocol \#22: Guidelines for Management of Jaundice)

i. Starvation jaundice of the newborn associated with poor breast milk intake despite appropriate intervention. This characteristically begins at 2-5 days and is marked by ongoing weight loss, limited stooling and voiding with uric acid crystals.

ii. Breast milk jaundice when levels reach 340-425 $\mu \mathrm{mol} / \mathrm{L}(20-25 \mathrm{mg} / \mathrm{dL})$ in an otherwise thriving infant and where a diagnostic and/or therapeutic interruption of breastfeeding may be under consideration. First line diagnostic management should include laboratory evaluation, instead of interruption of breastfeeding.

d. Macronutrient supplementation is indicated, such as for the rare infant with inborn errors of metabolism.

2. Maternal indications

a. Delayed secretory activation (day 3-5 or later [72-120 hours] and inadequate intake by the infant). ${ }^{80}$

b. Primary glandular insufficiency, (less than $5 \%$ of women - primary lactation failure), as evidenced by abnormal breast shape, poor breast growth during pregnancy or minimal indications of secretory activation..$^{84,85}$

C. Breast pathology or prior breast surgery resulting in poor milk production. ${ }^{84}$

d. Temporary cessation of breastfeeding due to certain medications (e.g. chemotherapy) or temporary separation of mother and baby without expressed breast milk available.

e. Intolerable pain during feedings unrelieved by interventions. 
TABLE 2. Average Reported Intakes of Colostrum by Healthy, Term Breastfed Infants ${ }^{62-65}$

\begin{tabular}{|l|l|}
\hline Time & Intake $(\mathrm{mL} /$ feed $)$ \\
\hline $1^{\text {st }} 24$ hours & $2-10$ \\
\hline $24-48$ hours & $5-15$ \\
\hline $48-72$ hours & $15-30$ \\
\hline $72-96$ hours & $30-60$ \\
\hline
\end{tabular}

Appendix 1 Inappropriate Reasons for supplementation in the context of a healthy newborn and mother, Responses, and Risks

\begin{tabular}{|c|c|c|}
\hline $\begin{array}{l}\text { Concerns/inappropriate } \\
\text { reasons }\end{array}$ & Responses & Risks of supplementation \\
\hline $\begin{array}{l}\text { There is "no milk", }{ }^{5} \text { belief that } \\
\text { colostrum is insufficient until } \\
\text { the milk "comes in" }\end{array}$ & $\begin{array}{l}\text { - Mother and family should be } \\
\text { educated about the benefits of } \\
\text { colostrum including dispelling } \\
\text { myths about the yellow color. } \\
\text { Small amounts of colostrum } \\
\text { are normal, physiologic, and } \\
\text { appropriate for the term, } \\
\text { healthy newborn. }\end{array}$ & $\begin{array}{l}\text { - Can alter infant bowel flora } \\
\text { and microbiome. }{ }^{86,87} \\
\text { - Potentially sensitizes the } \\
\text { infant to foreign proteins. }{ }^{88,89} \\
\text { - Increases the risk of diarrhea } \\
\text { and other infections, especially } \\
\text { where hygiene is poor. }{ }^{3} \\
\text { - Potentially disrupts the } \\
\text { "supply-demand" cycle, leading } \\
\text { to inadequate milk supply and } \\
\text { long-term supplementation }\end{array}$ \\
\hline $\begin{array}{l}\text { Supplementation is needed to } \\
\text { prevent weight loss and } \\
\text { dehydration in the postnatal } \\
\text { period }^{5}\end{array}$ & $\begin{array}{l}\text { - A certain amount of weight } \\
\text { loss is normal in the first week } \\
\text { of life and is due to diuresis of }\end{array}$ & $\begin{array}{l}\text { - Supplementation in the first } \\
\text { few days may interfere with the } \\
\text { normal frequency of } \\
\text { breastfeeding. }\end{array}$ \\
\hline
\end{tabular}




\begin{tabular}{|c|c|c|}
\hline & $\begin{array}{l}\text { extracellular fluid and passage } \\
\text { of meconium. }\end{array}$ & $\begin{array}{l}\text { - Supplementation with water } \\
\text { or glucose water, increases the } \\
\text { risk of jaundice, }{ }^{90} \text { excessive } \\
\text { weight loss, }{ }^{91} \text { and longer } \\
\text { hospital stays. }{ }^{92}\end{array}$ \\
\hline $\begin{array}{l}\text { Infant could become } \\
\text { hypoglycemic }\end{array}$ & $\begin{array}{l}\text { - Healthy, full-term infants do } \\
\text { not develop symptomatic } \\
\text { hypoglycemia as a result of } \\
\text { suboptimal breastfeeding. }{ }^{15}\end{array}$ & $\begin{array}{l}\text { - Same risks as for weight loss/ } \\
\text { dehydration }\end{array}$ \\
\hline $\begin{array}{l}\text { Breastfeeding is related to } \\
\text { jaundice in the postnatal } \\
\text { period }\end{array}$ & $\begin{array}{l}\text { - The more frequent the } \\
\text { breastfeeding, the lower the } \\
\text { bilirubin level. }{ }^{93,94} \\
\text { - Bilirubin is a potent } \\
\text { antioxidant }{ }^{95} \text { and jaundice is } \\
\text { normal in the newborn. } \\
\text { - Colostrum acts as a natural } \\
\text { laxative helping to eliminate } \\
\text { meconium that contains } \\
\text { bilirubin. } .^{94}\end{array}$ & $\begin{array}{l}\text { - Same risks as for weight } \\
\text { loss/dehydration }\end{array}$ \\
\hline $\begin{array}{l}\text { Lack of time for counseling } \\
\text { mother about exclusive } \\
\text { breastfeeding when mothers } \\
\text { request a supplement }\end{array}$ & $\begin{array}{l}\text { - Train all staff in how to assist } \\
\text { mothers with breastfeeding. } \\
\text { - Mothers may benefit from } \\
\text { education about artificial feeds } \\
\text { and/or how supplements may } \\
\text { adversely affect subsequent } \\
\text { breastfeeding. }\end{array}$ & $\begin{array}{l}\text { - If the supplement is infant } \\
\text { formula, which is slow to empty } \\
\text { from the stomach }{ }^{96} \text { and often } \\
\text { fed in larger amounts, }{ }^{66} \text { the } \\
\text { infant will breastfeed less } \\
\text { frequently. } \\
\text { - Depending on the method of } \\
\text { supplementation, }{ }^{52,74} \text { or the } \\
\text { number of supplements }{ }^{97} \text { an }\end{array}$ \\
\hline
\end{tabular}




\begin{tabular}{|c|c|c|}
\hline & $\begin{array}{l}\text { - Time spent by health care } \\
\text { professionals listening to and } \\
\text { talking with mothers is at least } \\
\text { as important as other more } \\
\text { active interventions (which } \\
\text { may be viewed more as "real } \\
\text { work" to them). }{ }^{29}\end{array}$ & $\begin{array}{l}\text { infant may have difficulty } \\
\text { returning to the breast. } \\
\text { - Feeds given before secretory } \\
\text { activation and copious breast } \\
\text { milk production (as opposed to } \\
\text { supplementation) may be } \\
\text { associated with delayed } \\
\text { initiation of breastfeeding and } \\
\text { negatively associated with } \\
\text { exclusivity and duration of } \\
\text { breastfeeding. }{ }^{98}\end{array}$ \\
\hline $\begin{array}{l}\text { Medications may be } \\
\text { contraindicated with } \\
\text { breastfeeding }\end{array}$ & $\begin{array}{l}\text { - Accurate references are } \\
\text { available to providers (e.g., } \\
\text { Medications and Mothers' Milk } \\
2017,{ }^{99} \text { LactMed on Toxnet } \\
\text { website }{ }^{15} \text { ) } \\
\text { - For most medical conditions, } \\
\text { medication safe for } \\
\text { breastfeeding mothers and } \\
\text { babies, is available }\end{array}$ & $\begin{array}{l}\text { - Risk of decreasing } \\
\text { breastfeeding duration or } \\
\text { exclusivity }{ }^{9,10}\end{array}$ \\
\hline $\begin{array}{l}\text { Mother is too malnourished } \\
\text { or sick to breastfeed or eats } \\
\text { an inappropriate diet. }\end{array}$ & $\begin{array}{l}\text { - Even malnourished mothers } \\
\text { can breastfeed. Breast milk } \\
\text { quality and quantity is only } \\
\text { affected in extreme } \\
\text { circumstances. Supplements } \\
\text { are better given to the mother } \\
\text { (with continued breastfeeding) } \\
\text { than the infant. }\end{array}$ & $\begin{array}{l}\text { - Risk of decreasing } \\
\text { breastfeeding duration or } \\
\text { exclusivity }\end{array}$ \\
\hline
\end{tabular}




\begin{tabular}{|c|c|c|}
\hline $\begin{array}{l}\text { Supplementation will quiet a } \\
\text { fussy or unsettled infant }{ }^{5}\end{array}$ & $\begin{array}{l}\text { - Infants can be unsettled for } \\
\text { many reasons. They may wish } \\
\text { to cluster feed or simply need } \\
\text { additional skin-to-skin time or } \\
\text { holding. }{ }^{67} \\
\text { - Filling (and often overfilling) } \\
\text { the stomach with a supplement } \\
\text { may make the infant sleep } \\
\text { longer, }{ }^{96} \text { missing important } \\
\text { opportunities to breastfeed, } \\
\text { and demonstrating to the } \\
\text { mother a short-term solution } \\
\text { which may generate long-term } \\
\text { health risks. } \\
\text { - Teaching other soothing } \\
\text { techniques to new mothers } \\
\text { such as breastfeeding, } \\
\text { swaddling (but not if prone or } \\
\text { side lying), }{ }^{100} \text { swaying, singing } \\
\text { techniques, encouraging father } \\
\text { or other relatives to assist. } \\
\text { Caution should be taken to not } \\
\text { ignore early feeding cues. }{ }^{101} \\
\text { latch to maximize signal to } \\
\text { moth body and intake for }\end{array}$ & $\begin{array}{l}\text { - Risk of decreasing } \\
\text { breastfeeding duration or } \\
\text { exclusivity } \\
\text { - Maternal engorgement due to } \\
\text { decreased frequency of } \\
\text { breastfeeding in the immediate } \\
\text { postpartum period. }{ }^{54}\end{array}$ \\
\hline $\begin{array}{l}\text { Concern about the cause of } \\
\text { frequent feeding and cluster }\end{array}$ & $\begin{array}{l}\text { - Periods when infants demand } \\
\text { to breastfeed more are } \\
\text { sometimes interpreted by }\end{array}$ & $\begin{array}{l}\text { - Risk of decreasing } \\
\text { breastfeeding duration or } \\
\text { exclusivity }\end{array}$ \\
\hline
\end{tabular}




\begin{tabular}{|c|c|c|}
\hline $\begin{array}{l}\text { feeding and other changes in } \\
\text { infant behavior }\end{array}$ & $\begin{array}{l}\text { mothers as insufficient milk. } \\
\text { This may happen in later weeks } \\
\text { but also in the second or third } \\
\text { night (48-72 hours) post birth. } \\
\text { - Changes in stooling patterns } \\
\text { that often occur after 6-8 } \\
\text { weeks of age can also be } \\
\text { misinterpreted as insufficient } \\
\text { milk. } \\
\text { - Anticipatory guidance for } \\
\text { normal infant development and } \\
\text { behaviour is helpful. }\end{array}$ & \\
\hline Mothers need to rest or sleep & $\begin{array}{l}\text { - Postpartum mothers are } \\
\text { restless when separated from } \\
\text { their infants and actually get } \\
\text { less rest. }^{29} \\
\text { - Mothers lose the opportunity } \\
\text { to learn their infants' normal } \\
\text { behavior and early feeding } \\
\text { cues. }^{48} \\
\text { - Infants are at highest risk for } \\
\text { receiving a supplement } \\
\text { between } 7 \text { p.m. and } 9 \text { a.m. }{ }^{102}\end{array}$ & $\begin{array}{l}\text { - Risk of decreasing } \\
\text { breastfeeding duration or } \\
\text { exclusivity }\end{array}$ \\
\hline $\begin{array}{l}\text { Sore nipples will improve if } \\
\text { mother takes a break from } \\
\text { breastfeeding } 5\end{array}$ & $\begin{array}{l}\text { - Sore nipples are not a } \\
\text { function of length of time } \\
\text { breastfeeding. Position, latch, } \\
\text { and sometimes individual } \\
\text { anatomic variation (e.g. }\end{array}$ & $\begin{array}{l}\text { - Problem with latch not } \\
\text { addressed } \\
\text { - Risk of decreasing } \\
\text { breastfeeding duration or } \\
\text { cessation of breastfeeding }\end{array}$ \\
\hline
\end{tabular}




\begin{tabular}{|c|c|c|}
\hline & $\begin{array}{l}\text { ankyloglossia) are more } \\
\text { important. }{ }^{103} \\
\text { - There is no evidence that } \\
\text { limiting time at the breast will } \\
\text { prevent sore nipples. } \\
\text { - The nipple should not be } \\
\text { rubbed or compressed during } \\
\text { breastfeeding even if the } \\
\text { feedings are frequent or } \\
\text { "clustered". }{ }^{104}\end{array}$ & - Risk of breast engorgement \\
\hline
\end{tabular}

Appendix 2: - see separate file 